ENTREPRENEURSHIP AND SUSTAINABILITY ISSUES

ISSN 2345-0282 (online) http://jssidoi.org/jesi/

2020 Volume 7 Number 3 (June)

http://doi.org/10.9770/jesi.2020.7.3(13)

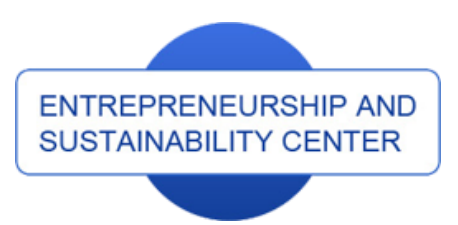

Publisher

http://jssidoi.org/esc/home
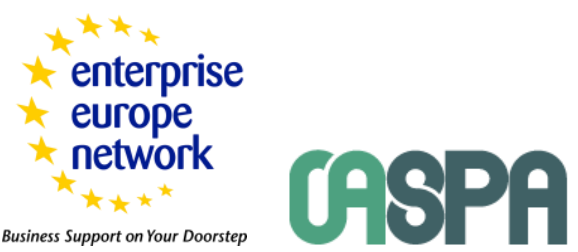

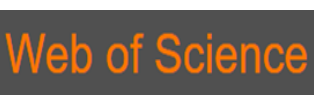

Clarivate

Analytics

\title{
CAN LOCAL GOVERNMENT IMPACT TRANSACTION COSTS OF ENTERPRISES?*
}

\author{
Anna Mempel-Śnieżyk ${ }^{1}$, Niki, Derlukiewicz ${ }^{2}$, Tomasz Pilewicz ${ }^{3}$, Małgorzata Zdon-Korzeniowska ${ }^{4}$ \\ 1,2 Wroclaw Uniwersity of Economics, Komandorska Street 118/120, 53-345 Wrockaw, Poland \\ ${ }^{3}$ Collegium in Business Administration of Economic Science of Warsaw School of Economics, Niepodległości 162, \\ 02-554 Warsaw, Poland \\ ${ }^{4}$ Pedagogical University of Cracow, Podchorażych 2, 30-084 Cracow, Poland
}

\begin{abstract}
E-mails: ${ }^{1}$ anna.sniezyk@ue.wroc.pl , $^{2}$ niki.derlukiewicz@ue.wroc.pl, ${ }^{3}$ tomasz.pilewicz@sgh.waw.pl
${ }^{4}$ malgorzata.zdon-korzeniowska@up.krakow.pl
\end{abstract}

Received 17 September 2019; accepted 20 December 2019; published 30 March 2020

\begin{abstract}
The paper raise the issue of theoretical aspects of local development and transaction costs. The main aim of the paper was to identify investment incentives offered by the local government and to recognize their importance in reducing enterprise transaction costs. The article discuss the findings on the enterprise transaction costs in the relation to the local governments and their potential investment attractiveness. To this end the correlation between potential investemnent attractiveness of local governments and their investment incentives offer was analysed. Authors presented the results of the research conducted in Poland regarding investment incentives offered at the local level. Moreover, a typology of investment incentives (financial and non-financial) offered by the local government, which can result in reducing the enterprise TCs, were pointed out.
\end{abstract}

Keywords: entrepreneurship; local government; transaction cost; investment incentives; investment attractiveness; Poland

Reference to this paper should be made as follows: Mempel-Śnieżyk, A., Derlukiewicz, N., Pilewicz, T., Zdon-Korzeniowska, M. 2020. Can local government impact transaction costs of enterprises? Entrepreneurship and Sustainability Issues, 7(3), 1612-1631. https://doi.org/10.9770/jesi.2020.7.3(13)

JEL Classifications: H80, D23, H11, H70

\footnotetext{
* The project is financed by the Ministry of Science and Higher Education in Poland under the programme "Regional Initiative of Excellence" 2019 - 2022 project number 015/RID/2018/19 total funding amount 10 721 040,00 PLN
} 


\section{ENTREPRENEURSHIP AND SUSTAINABILITY ISSUES}

ISSN 2345-0282 (online) http://jssidoi.org/jesi/

2020 Volume 7 Number 3 (June)

http://doi.org/10.9770/jesi.2020.7.3(13)

\section{Introduction}

Globalization, regionalization, role of small and medium enterprises in economic development and the increasing importance of entrepreneurship stimulation policies drew attention of many researchers to local and regional causes. Creating a pro-innovative and pro-entrepreneurial environment is generally seen as a government task and the entrepreneurial behaviour is more commonly seen as the private sector domain. The interest in what we might call public sector and entrepreneurship is developing. The notion of pro-entrepreneurial government has been used in a number of divergent contexts eg. Bellone, Goerl, Moon, Shockley, Frank, Stough (Luke, Verreynne, Kearins 2010).

The role of local government (LG) in socio-economic development is not a new issue and it is discussed in the subject literature on local economic development (Collinge 1992). There have been conducted both theoretical and empirical research in this field (Xiaohong, Chen 2016). Scientist from 70' investigate LG economic role (Johnson, Cochrane 1981). The LG interacts with residents and the private sector, as well as serves services for residents and businesses (Thomo, Littunen. Storhamar 2010). Therefore, the role of LG is crucial in fulfilling needs of citizens and entrepreneurs (Moschidis, Ismyrlis 2018).

Local development (LD) it is a process that takes place in a particular territory and depends on the ability to create and stimulate its own development. LD as a specific category of socio-economic development is defined as qualitative changes related to a given area in terms of the standard of living of the population and the conditions of functioning of economic entities (Pike, Rodriguez-Pose, Tomaney 2017). LD initiatives are aimed at boosting the economy through the use of local resources. This is so-called bottom-up development (Kisman,Tasar 2014). However, in the context of regional development there also exists a top-down approach and it is important that bottom up initiatives should be skillfully linked to top-down central-level policies. Top-down approaches take into account the socio-economic environment and external factors in the socio-economic development process. Main theories concerning top-down development are represented inter alia by Smith, Ricardo, Keynes, North, Innes, Myrdal, Schumpeter, Hirschman, Perroux, Friedmann and others. According to the above-mentioned authors LD is supported by central authorities and diffusion of development generated in regions by leading centers (centers, cores) (Dzwigol et al. 2019). It is worthwhile to note that Nelson presents applying regional development theory to LD policy and he also presents both development-from-the-above and development-frombelow schools in regional development (Bingham, Mier 1993). The LD requires actions at the local level that address the unique character of a particular territory. LD may be identified with intentional actions of local authorities which are aimed at creating new values as well as rational and effective use of human, natural, and cultural resources. A local government is not the only subject implementing LD but there are also nongovernmental organizations, enterprises and the local society.

The role of LG in the context of supporting entrepreneurship is not new and it is discussed in the subject literature. To explain it, it is worth to mention approaches of neo-Marshallian Italian theorists who were explaining the phenomenon of the new industrial districts. The pioneers in the research were Becattini (1992), Bagnasco (1977) and then developed by researchers such as Stöhr, Ciciotti, Wettmann: indigenous potential, Johannison: local context, Secchi and Garofoli: system areas, Courlet-Bernard Pecqueur and Ganne: localized industrial system (Capello 2011). Moreover the past two decades have witnessed pressure on local authorities to become more entrepreneurial (Bond 2005).

In the paper we concentrate on the LG activities which indirectly contribute to LD. A local government is an important subject influencing investment that significantly contributes to local and regional development Gorzelak, Grosse, Miszczuk, Dziemianowicz (Serocka 2016). It has been obligated to perform both obligatory tasks as well as facultative tasks, aiming at satisfying the needs of local society as well as programming and 


\section{ENTREPRENEURSHIP AND SUSTAINABILITY ISSUES}

ISSN 2345-0282 (online) http://jssidoi.org/jesi/

2020 Volume 7 Number 3 (June)

http://doi.org/10.9770/jesi.2020.7.3(13)

implementation of LD. It should be emphasized that LGs create a local social-economic reality. LG is oriented to the needs of a given local community, the possibilities of reasonable utilization of this area resources, the level of infrastructure, education etc. LG provides the unique added value to the development process. Apart from the activities defined above, local authorities exceed their locality and play an important role in accelerating the development process. LG is responsible for the issues related to current and future needs of a local community, inter alia for forecasting development directions, tendencies and development barriers, prevention of barriers formation and creation of cooperation system. LG are creators of development processes - they undertake actions to create conditions for the development of entrepreneurship and support it. LG initiates changes and implements stimulating entrepreneurship policies. It is regarded as formally responsible for undertaking activities which result in certain local regions being attractive for a potential entrepreneur (Lakshmanan, Chatterjee 2009).

In the paper we concentrate on the LG's activities which can contribute to LD. The starting point for our research was our perception that in a rapidly changing economy, which is dominated by technological progress and eeconomy, the realities of functioning of the LG have also changed. We claim that websites of LG are becoming more and more popular and important for clients - entreprenuers. The website of a particular LG is the place which is visited by an entrepreneur as the first one to search for information. Therefore, the data placed there and the way they are communicated may have an impact on reducing the TCs for an entrepreneur. The access to information, transparency of the investment offer, its readability and accuracy have an impact on the time that entrepreneur can devote to obtain and verify the aforementioned information. In addition, the readiness and response of the local authorities in the context of entrepreneurship is crucial.

We claim that the activity of the LG in the field of creating investment incentives which are designed to meet the needs of a particular locality can result in reducing the enterprise TCs.

The aim of the paper is to identify investment incentives offered by the LG and to recognize their importance in reducing enterprise TCs. To this end, we designed and conducted nonreactive and reactive research. According to the triangulation method, our research were based on the following methods: desk research, electronic audit, electronic survey and mystery client. The detailed methodology of the study, sampling frame and selection of the research sample are outlined in this paper. To identify financial and non-financial examples of investment incentives offered at the local level by the LGs in Poland we used desk research as well as survey.

To reach the main goal of the paper we formulated the following research hypothesis:

1. Local regions with the higher PIA (class A, B, C) offer more investment incentives and have higher level of pro-entrepreneurial behaviour can be observed.

2. Pro-entrepreneurial behavior and investment incentives offered by the LGs influence on reducing enterprise transaction cost.

What we understand as pro-entrepreneurial behaviour is behaviour such as permanent readiness for cooperation and quick reaction and response of the LGs to the needs of entrepreneurs in a new business creation context. Success in initiating and driving the European funding process involved proactiveness, innovation, risk-taking, leadership and creativity, a combination of attributes associated with entrepreneurial behaviour. Wrote about it eg. Miller and Friesen, Timmons and Spinelli.

In the paper we examined dependencies between the level of potential investment attractiveness (PIA) indicator of local regions and their pro-entrepreneurial behavior, as well as their response to the electronic survey and a mysterious customer. In order to confirm the dependence between PIA and pro-entrepreneurial behaviour we used statistical tools.

Furthermore, our research was concentrated on examining how Polish LGs have prepared their websites in the context of their investment offer. We verified the LGs readiness to help and cooperate with entrepreneurs, and 


\section{ENTREPRENEURSHIP AND SUSTAINABILITY ISSUES}

ISSN 2345-0282 (online) http://jssidoi.org/jesi/

2020 Volume 7 Number 3 (June)

http://doi.org/10.9770/jesi.2020.7.3(13)

also pointed out what kind of investment incentives (financial and non-financial) they offer, which can result in reducing the enterprise TCs.

It is worth to mention about interesting empirical research aimed at how institutional environment specific factors affect the dynamics of entreprenership that was conducted by Roman, Rusu, Stoica (Roman et all. 2017). Their research presented the new expectations towards LGs and new tasks that result from the progressing process of socio-economic development and socio-political changes.

The interesting research was an object of investigation presented by other researchers in the report entitled Institutional efficiency and local economic development-factors and interactions (Marks-Bielska et all. 2017). The researchers introduced the concept of institutional efficiency and define it as "permanent readiness to maintain partner economic and social relations, both with entrepreneurs and with the local community; the ability of a quick, competent response of the local authorities to the needs of entrepreneurs who intend to establish and run a company in a given local region." (Marks-Bielska et all. 2017). These studies confirm the validity of the analyzed topic, emphasize the role of the LG authorities and their pro-entrepreneurial attitudes in the LD.

\section{Pro-entrepreneurial incentives of local government in creating investment attractiveness and reduction transaction costs of enterprises}

The significant role of entrepreneurship in the economic development is an interest of scholars and policy makers at various levels (Eddelani et al., 2019; Sasongko et al., 2019; Petrenko et al., 2019; Orynbassarova et al., 2019). One can find in literature the investigation concerning the dynamics of entrepreneurship in different countries depending on the lifecycle of business in order to identify the segments that require at most support of public authorities. The ability of LGs to attract entrepreneurs and to entice them to locate and conduct their business activity in their local region, is called investment attractiveness (IA) (Jac, Vondrackova 2017). IA is perceived as meeting the expectations of enterprises while considering investing in a defined investment location (GodlewskaMajkowska 2011). According to the Gdańsk Institute for Market Economics, IA „,is understood as a capability to attract investment through a combination of business benefits linked to location. The areas that produce an optimal combination of location factors offer the best conditions to business operators and hence attract investment" (Nowicki 2012). Investment attractiveness is also defined on the basis of the location determinants leading to the reduction of investment and operational costs of an enterprise, thus contributing to maximization of profits and the reduction of risk of the investment failure. (Šebestová et al. 2015). The entrepreneur locating business in the local region decides for a certain offer and enters a specific environment of an enterprise (O'Gorman, Kautonen 2004). Moreover, the group of factors or incentives that determine the company's location decision are not universal and might heavily depend on the LGs policies, specific assets, local strategies of development etc. Moreover, the entrepreneurs' decisions are influenced by access to information (the possibility of obtaining necessary information in order to reduce TC of enterprises (see picture 1). Therefore, in order to reduce a company's TC, the LGs should consciously tackle the easiness in availability of information characterizing a certain local region and should also inform and ensure favorable policy for entrepreneurs starting their businesses (Taylor 2006).

Transaction cost analysis is recognized as crucial in new institutional economics: Coase, Davis and North, Alchian and Demsetz, North, Williamson (1998), Klein, Crawford, and Alchian, Wiliamson, which focuses on how institutional rules structure the process of economic exchange (Lubell et all. 2017).

TC might consist of, among others, communication costs, time costs, government fees, taxes, information and search costs, administration costs and brokerage commissions. Throughout the literature, authors are mainly interested in studying the influence of transaction costs on portfolio choice and stock pricing (Ismael 2017). 


\section{ENTREPRENEURSHIP AND SUSTAINABILITY ISSUES}

ISSN 2345-0282 (online) http://jssidoi.org/jesi/

2020 Volume 7 Number 3 (June)

http://doi.org/10.9770/jesi.2020.7.3(13)

TC are understood as costs occurring in the process of economic exchange between the exchange parties. They include among others the costs of checking the other party, costs of a contact resulting from the economic transaction, costs of transaction negotiations, costs of transaction contract creation, or costs of contract execution monitoring. In the context of the investment attractiveness and search of investment location, TC occur in relation to the identification and selection of the investment area (greenfield, brownfield), recruitment and training of employees, identification and contracting of suppliers. All these costs can be minimized by the LGs acting as a broker consciously minimizing asymmetry of information searched by transaction parties. Activities and services aiming at mitigation of transaction risk and elimination of information asymmetry between transaction parties maximize frequent and successful contracting (Hwang 2015).

The range of TC might vary depending on quality of formal and informal institutions in the defined locations. Therefore the potential investment attractiveness of a given location results from the preferences and choices of entrepreneurs willing to conduct economic transactions in that location. The transaction costs theory is directly linked with the school of new institutional economics (NIE). Formal and informal institutions are the key research subject of NIE and therefore it can influence minimization of TC for parties, and this way they have an impact on the attractiveness of economic exchange.

The literature review demonstrates that entrepreneurship in public organizations is a phenomenon that has been investigated very little to date, especially in the entrepreneurship literature. The existing studies are mainly conceptual (based on intuition or informal opinion) and non-cumulative. The main methods used to provide evidence are ad hoc biographies or case studies. Additionally, this paper attempts to fill the literature gap by empirically testing the applicability of the concept of public sector entrepreneurship in the context of European local government (Zerbinati, Souitaris 2005).

\section{The methodology of the research}

In order to compliment the empirical research, we decided to use the Boolean keyword searching and subject term searching in the following databases: EBSCO, Emerald and Google Scholar. The authors used these databases to search for phrases reflecting the investigated issues (local development, local government, transaction cost, investment attractiveness) and Boolean search operators such as AND, NEAR and PHRASE. The research was conducted between 21st -24th of July 2017. We checked coexistence of entrepreneurial activities investment attractiveness and transaction costs with local development, and also local government in scholar publications. The detailed analysis of the Boolean search results conducted by the authors led them to the conclusion that there existed a research gap in the field of the investment attractiveness and entrepreneurial activities in the context of the TC incurred (being lowered) by enterprises.

In the context of the research sampling frame the authors used the population of all local regions in Poland and performed stratified random sampling. The Authors intended to link identified activities of local regions with their potential investment attractiveness. Therefore, the indicator of PIA of local regions was used to define subpopulations constituting the base for stratification within the sampling frame. The indicator in question was developed in Warsaw School of Economics by a team of researchers. The methodology of its calculation has been thoroughly described in the subject literature (Godlewska- Majkowska, 2011). According to this methodology, the level of the potential investment attractiveness of a given spatial unit is determined by a number of sub-indices, aggregated in the so-called microclimates. There exist 5 microclimates calculated to determine the level of the potential investment attractiveness of a spatial unit: human resources, technical infrastructure, social infrastructure, market, and administrative ones. Sub-indices are calculated on the basis of quantitative data collected by the Central Statistical Office of Poland. Therefore, they are standardized and comparable among all the local territorial units in the country. Consequently, the degree of variation in the average level of total potential investment attractiveness, based on these microclimates, is presented by a synthetic indicator of the PIA. 


\section{ENTREPRENEURSHIP AND SUSTAINABILITY ISSUES}

ISSN 2345-0282 (online) http://jssidoi.org/jesi/

2020 Volume 7 Number 3 (June)

http://doi.org/10.9770/jesi.2020.7.3(13)

(Godlewska- Majkowska, 2018). As a result, all the local regions in Poland can be classified into 6 classes ranging from the most (class A) to the least attractive (class F). In our paper we used the synthetic PIA index based on the public statistics of 31st December 2014. Stratification in our research sample selection reflected potential investment attractiveness classes from A to F and resulted in 277 local regions in the final sample the with assumed $95 \%$ level of confidence parameter and 5,5\% level of expected error rate. The following detailed information reflecting the sample used in the research is presented in Table 1.

Table 1. Research sample

\begin{tabular}{|c|c|c|}
\hline $\begin{array}{c}\text { Potential Investment } \\
\text { Attractiveness Class } \\
\text { (from A to F }\end{array}$ & $\begin{array}{c}\text { Total subpopulation of local regions } \\
\text { within Potential Investment } \\
\text { Attractiveness Class for 31st of } \\
\text { December }\end{array}$ & $\begin{array}{c}\text { Final sample of local regions } \\
\text { reflecting Potential Investment } \\
\text { Attractiveness, assumed level of } \\
\text { confidence and expected error rate }\end{array}$ \\
\hline A & 419 & 44 \\
\hline B & 229 & 13 \\
\hline C & 414 & 43 \\
\hline D & 585 & 86 \\
\hline E & 513 & 66 \\
\hline F & 319 & 25 \\
\hline
\end{tabular}

Source: Own elaboration.

The research was conducted using both nonreactive and reactive research methods. The basic nonreactive research method used was electronic audit of official websites of the local regions. This electronic audit consisted of analyzing the local regions websites with the application of a structured questionnaire composed of 42 questions bundled in thematic blocks focused on communication of a local region with an entrepreneur, a local region's investment offer, and local region investment incentives. The main purpose of the electronic audit was to identify and classify the content of the official websites of the local regions which could be useful for entrepreneurs. The electronic audit of all the 277 local regions with the usage of standardized set of questions and unified method of coding the answers was performed between 13th of July 2017 - 18th of August 2017.

What the authors decided to use as a reactive research method was the mystery customer method. We used the electronic correspondence prepared from the position of a company, which was sent to official electronic correspondence addresses of the local regions in the research sample. Our electronic account was created exclusively for the research purposes. The set correspondence consisted of a short introduction explaining the reason of the contact and 5 questions related to a new business activity planning to be set up in a given local region. We also enquired about the availability of the investment infrastructure, investment incentives and their support for entrepreneurs. The mystery customer research of all the 277 local regions with the usage of the standardized correspondence and a unified method of coding the answers was performed between 1st of August 2017 - 24th of August 2017. As 92 out of 277 local regions responded to the mystery customer, the response rate in the mystery customer method research was $33.2 \%$. All the received answers were coded afterwards. The electronic audit research and mystery customer research were complemented with an electronic survey sent to the official administrative representatives of the local regions in the sample. The electronic survey consisted of 5 questions related to the subjective perception of attractiveness of the investment offer, their approach toward the decrease of costs of a new business activity set up and the factors important in a new entrepreneur's attraction to the local region. The electronic survey research of all the 277 local regions with the usage of the standardized electronic survey questionnaire and the unified method of coding the answers was performed between 27th of July 2017 and 31st of August 2017. Among the 277 local regions research representatives only 33 sent filled questionnaires. The response rate in the electronic survey method was $11,9 \%$ and the received answers were coded properly. The empirical research data gathered with the usage of the above-mentioned methods and tools 
was analyzed with the application of both quantitative and qualitative data analysis methods including the usage of Statistica software version 13.1. The sampling frame, research sample and methods used in the research performed are presented in picture 1.

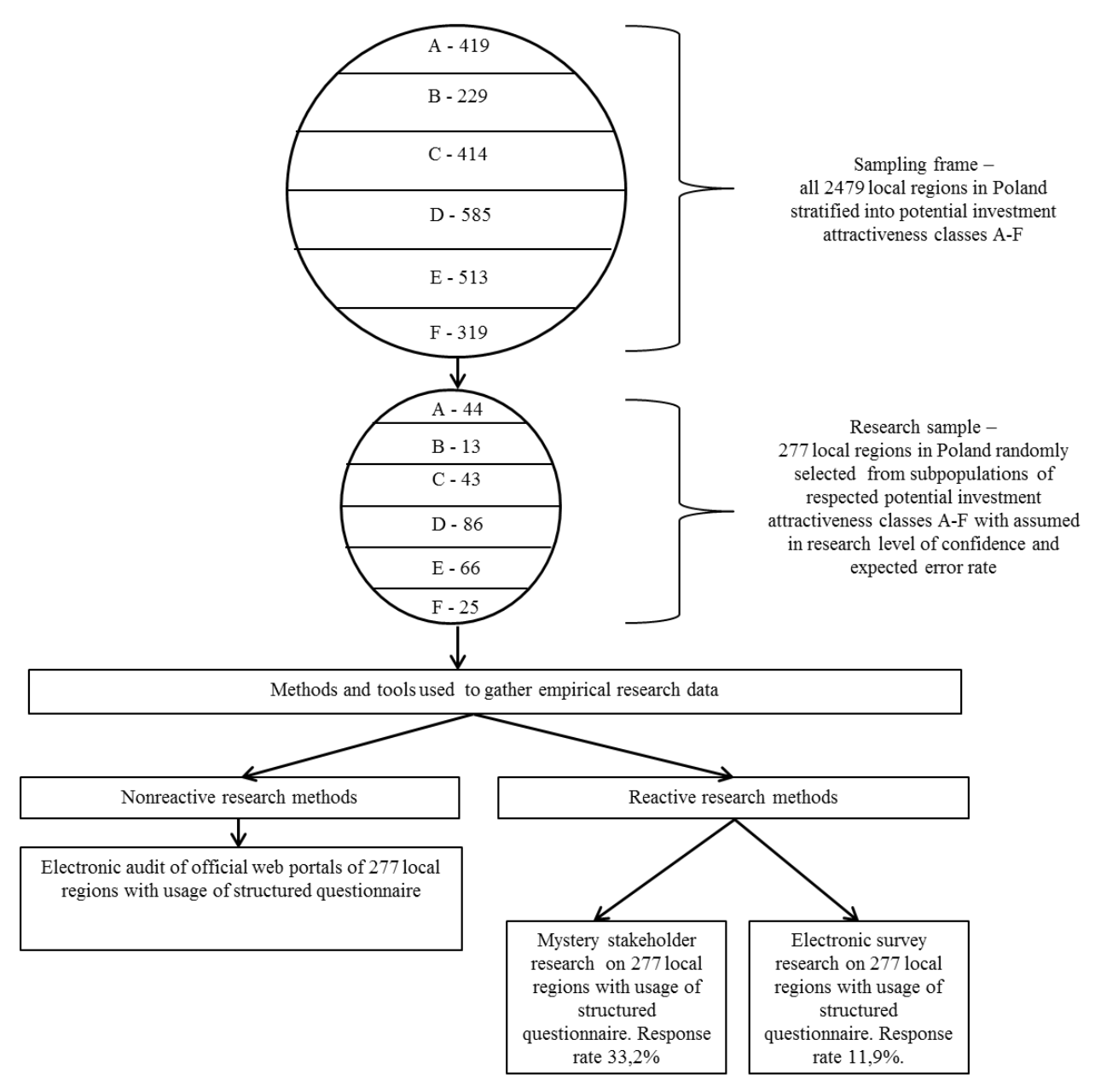

Picture 1. Sampling frame, research sample and methods used in research performed.

Source: Own elaboration.

\section{Results and discussion}

\subsection{Investment incentives of local government and reducing transaction costs for enterprises}

Investment incentives are usually defined as measures or instruments which objective is to influence size, location or sector of considered direct investment through minimization of relative investment costs or risks. Scholars distinguish among others fiscal incentives, which are the most popular ones and refer to lowering the basis for calculation of the income tax. Financial incentives, which refer to subsidies and participation in the costs of investment by investment attracting party and legal incentives which lead to exemption of entrepreneur from certain obligations. To identify investment incentives offered by the LGs we conducted a desk research, which allowed us to prepare a list of incentives important for potential investors in order to decrease TC of enterprises. 
The picture 2 presents local business environment in the context of investment attractiveness as well as investment incentives influencing TC of enterprises.

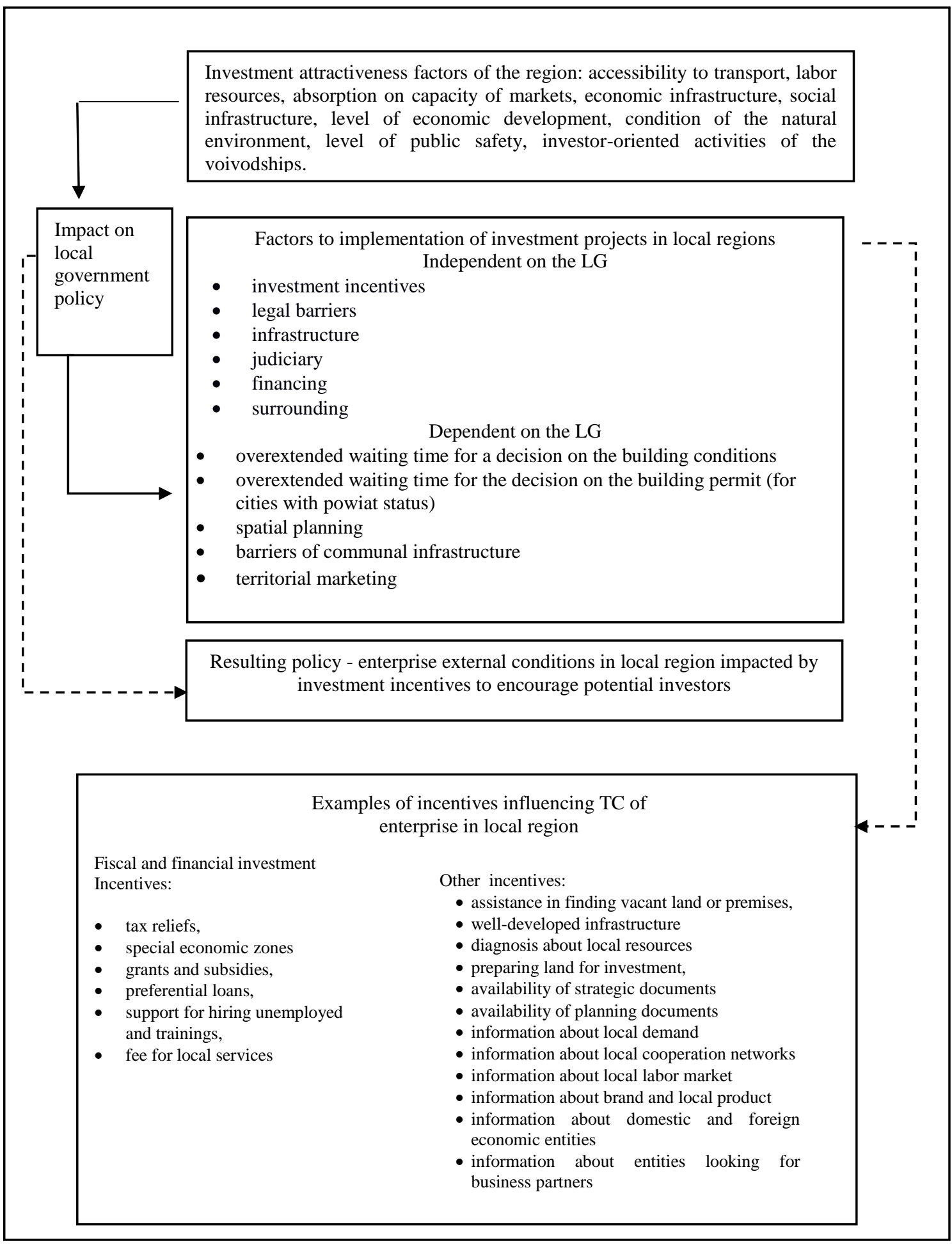

Picture 2. Scheme of local business environment in the context of investment attractiveness and investment incentives Source: own elaboration on basis (Maron 2013) 
ENTREPRENEURSHIP AND SUSTAINABILITY ISSUES

ISSN 2345-0282 (online) http://jssidoi.org/jesi/

2020 Volume 7 Number 3 (June)

http://doi.org/10.9770/jesi.2020.7.3(13)

The investment incentives offered to entrepreneurs include fiscal and financial encouragements. These incentives are designed to influence the attractiveness of certain local regions and to increase the financial efficiency of enterprises by reducing the cost of their current operations as well as their investment costs and taxes.

On that base we created a questionnaire used in the audit of particular local regions websites. The electronic audit allowed us to check which investment incentives are offered in the examined local regions to enterprises in the context of reducing their transaction costs. In the course of our electronic audit research we distinguished between fiscal and financial (investigated as one type) and other investment incentives offered by local regions to entrepreneurs. Among all the sample of 277 local regions researched, $15 \%$ of them communicated offer of fiscal and financial incentives in their official websites. On average $26 \%$ of local regions with high PIA (class A-B) offered fiscal and financial incentives, whereas in relation to local regions with medium PIA (class C-D) and low PIA (class E-F) it was respectively $18 \%$ and 5\%. Among fiscal and financial incentives offered, the most popular were exemption or decrease of local real estate tax, exemption or decrease of local vehicle tax, subsidy to settingup economic activity, and subsidy to employment of juvenile employees. Detailed distribution of fiscal and financial incentives offered by local regions in our sample is presented in figure 1.

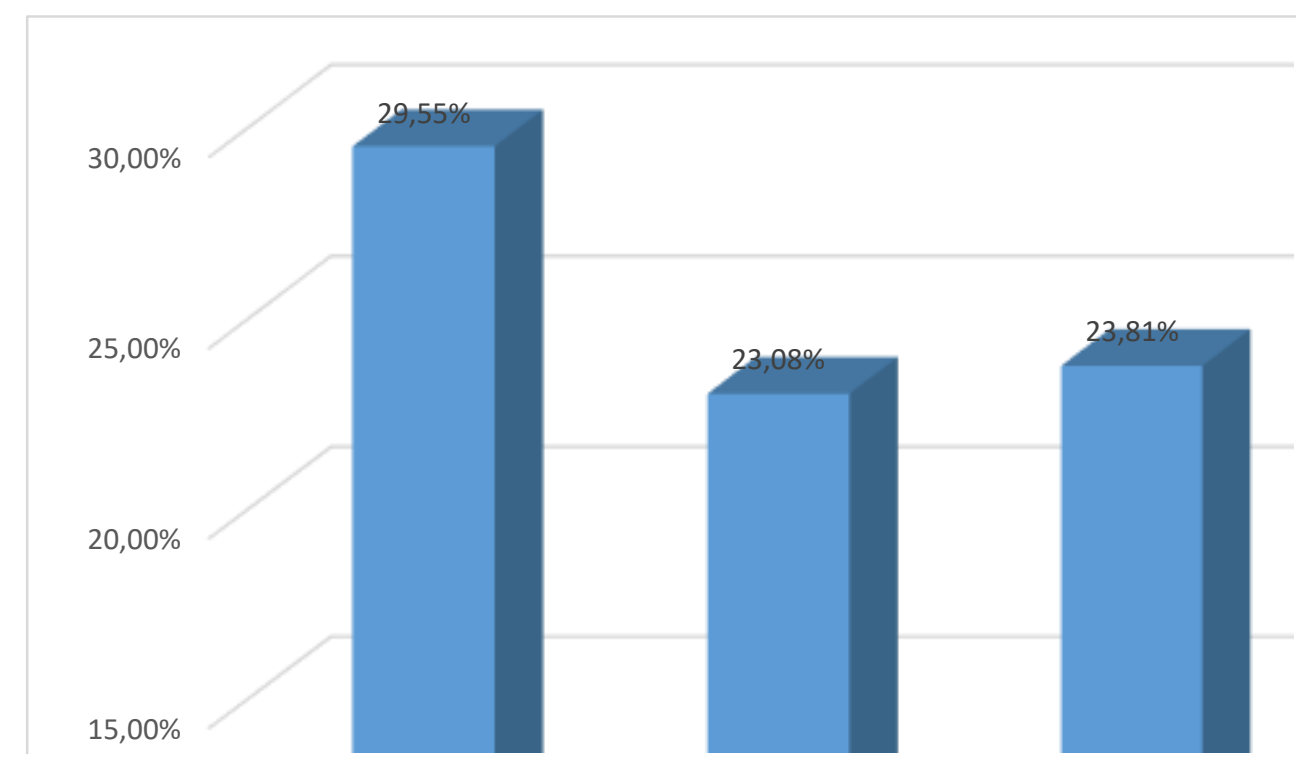

Figure 1. Percentage of local regions from the research sample with fiscal and financial incentives for entrepreneur communicated through their official website and their PIA (class A-B - high, class C-D - medium, class E-F - low) Source: Own study basing on research performed.

In our research we also investigated other investment incentives with intention to identify non-fiscal and nonfinancial ones. Among 277 examined local regions, 15\% of them communicated offer of non-financial and nonfiscal incentives in their official websites, but only a fourth of them belonged to the subpopulation of local regions that also offered fiscal and financial incentives elaborated above. Among the most interesting non-fiscal and nonfinancial incentives communicated in the official websites of local regions we identified offers of support in preparation of business plan, business advisory and business trainings, free of charge conference room for the use of entrepreneurs, or free of charge accounting services for starting entrepreneurs arranged by LG. Surprisingly these incentives were demonstrated mostly by local regions of medium PIA (class C-D) as they were offered on average by $16 \%$ of them. Local regions with the lowest PIA (E-F) and highest PIA (A-B) offered them with respectively $13 \%$ and $11 \%$ frequency. The difference in assumed high expectation toward demonstration of these type of incentives by high and medium class local regions resulted from the fact that high and medium class local 
regions offered more incentives of fiscal and financial type. There is no doubt that the calculation of statistical metric of average for high class local regions has been impacted by no incentives of that type identified among local regions of B class. Details are presented in the figure 2.

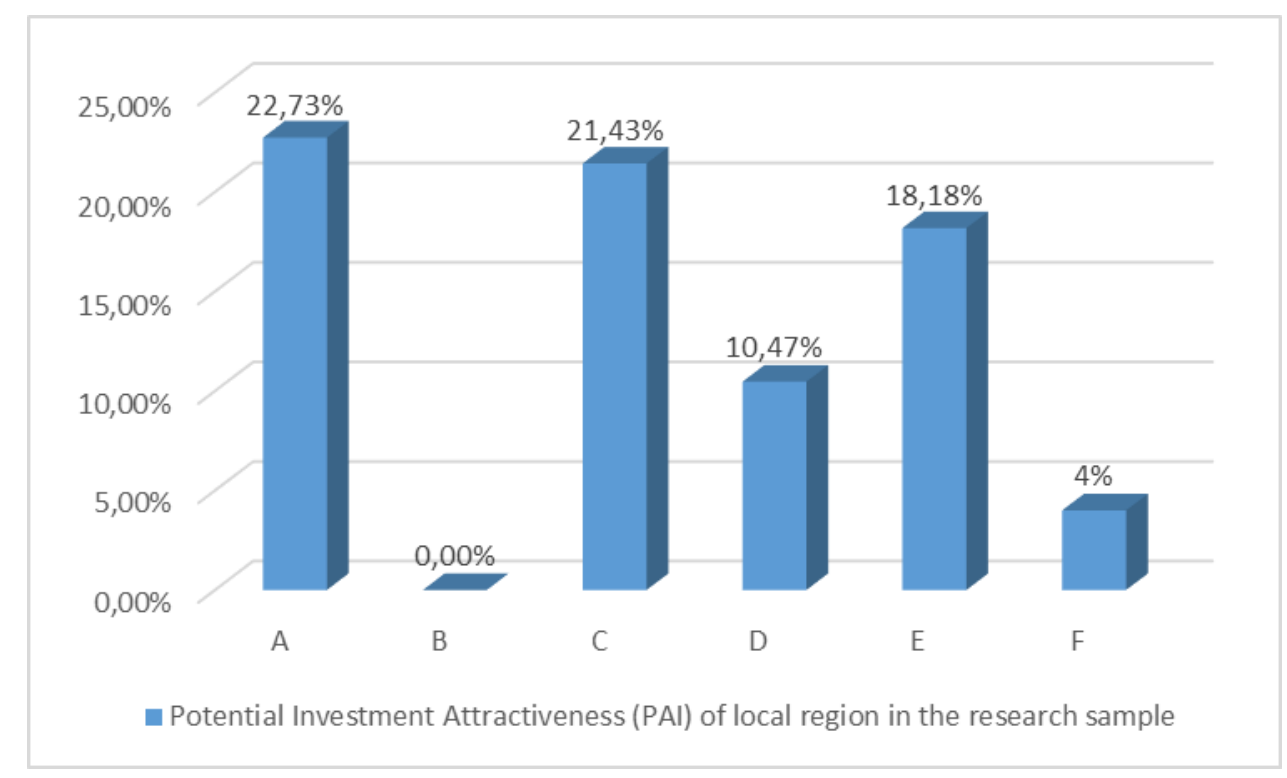

Figure 2. Percentage of local regions from the research sample with non-fiscal and non-financial incentives for entrepreneurs communicated through their official website and their PIA (class A-B - high, class C-D - medium, class E-F - low). Source: Own study basing on research performed.

Among the offers for entrepreneurs our particular attention was given to downloadable investment folders, brochures or movies, which presented benefits from locating an investment in defined spatial unit. In TC theory context such information has a certain value for entrepreneur as when it is not provided and location is considered, the information needs to be collected and analyzed either by entrepreneurs themselves or ordered as a service and paid for. New institutional economics analyses which alternative structures and activities of government reduce TC (Wojtyna, 2001). Referring to that, we have identified that almost 9\% from all local regions in our research sample offered professional, downloadable folder, brochure or movie on investment benefits related to their spatial area.

We have found out that a part of these resources were prepared in several language versions. Among all the types of local regions investigated, those of high PIA (class A-B) offered such material on average in $23 \%$ of cases, whereas in relation to local regions of medium PIA (class C-D) and low PIA (E-F) this frequency dramatically decreased and ranged respectively from $11 \%$ to $1,5 \%$. In our view as preparation of such materials is relatively non-intensive in terms of resources and costs, such low ratios among local regions with medium and low PIA are unsatisfactory and indicate room for sharing the best practices and improvement. Figure 3 presents details of the distribution of the answers received to question related to it. 


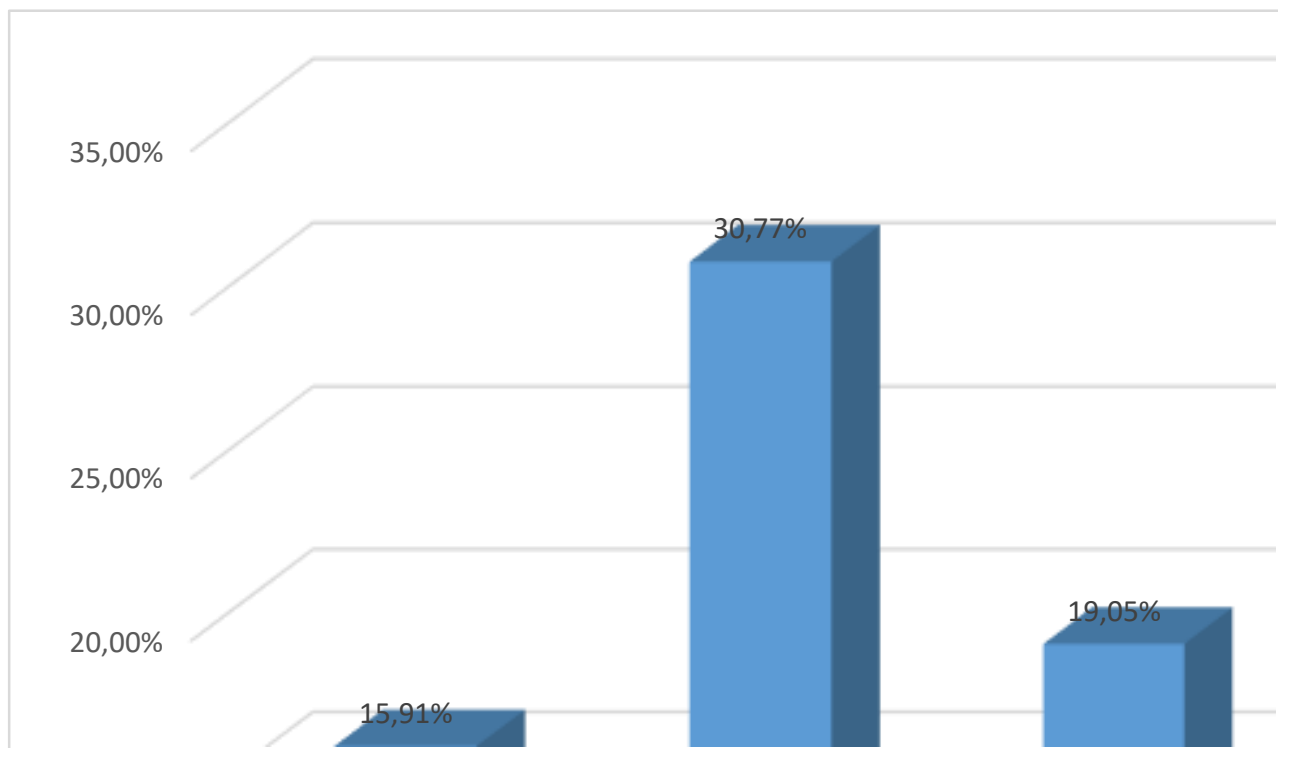

Figure 3. Percentage of local regions from the research sample with non-fiscal and non-financial incentives for entrepreneur communicated through their official website and their PIA (class A-B - high, class C-D - medium, class E-F - low).

Source: Own study basing on research performed.

\subsection{Pro-entrepreneurial incentives of local government in the context of investment attractiveness}

In our study we researched how many of investigated local regions communicate potentially required information for entrepreneurs in LG official websites, thus enabling access to this information, shortening the search time, and saving an enterpriser's time.

General information related to starting a new business was communicated by $12 \%$ of all 277 investigated local regions. On average $19 \%$ of local regions with high PIA (class A-B) offered information about starting a new business in their official websites, whereas in relation to local regions with medium PIA (class C-D) and low PIA (class E-F) it was respectively $11 \%$ and $6 \%$. It is worth to add, that only $3 \%$ of investigated local regions inform entrepreneurs through their websites about indirect advisory e.g. business consultancy, business plan consultancy, and for entrepreneurs this information seems to be really important from TC point of view. TC of enterprise, as mentioned above, can be reduced for instance by simplifying access to information on entrepreneurs located in local region. The electronic audit revealed surprisingly high percentage of investigated local regions (62\%) communicating on their websites information about enterprises located or operating in their area (see figure 4) The result are as follow: on average $80 \%$ of local regions with high PIA (class A-B), 63\% with medium PIA (class C-D) and 53\% of local region with low PIA (class E-F). 
ENTREPRENEURSHIP AND SUSTAINABILITY ISSUES

ISSN 2345-0282 (online) http://jssidoi.org/jesi/

2020 Volume 7 Number 3 (June)

http://doi.org/10.9770/jesi.2020.7.3(13)

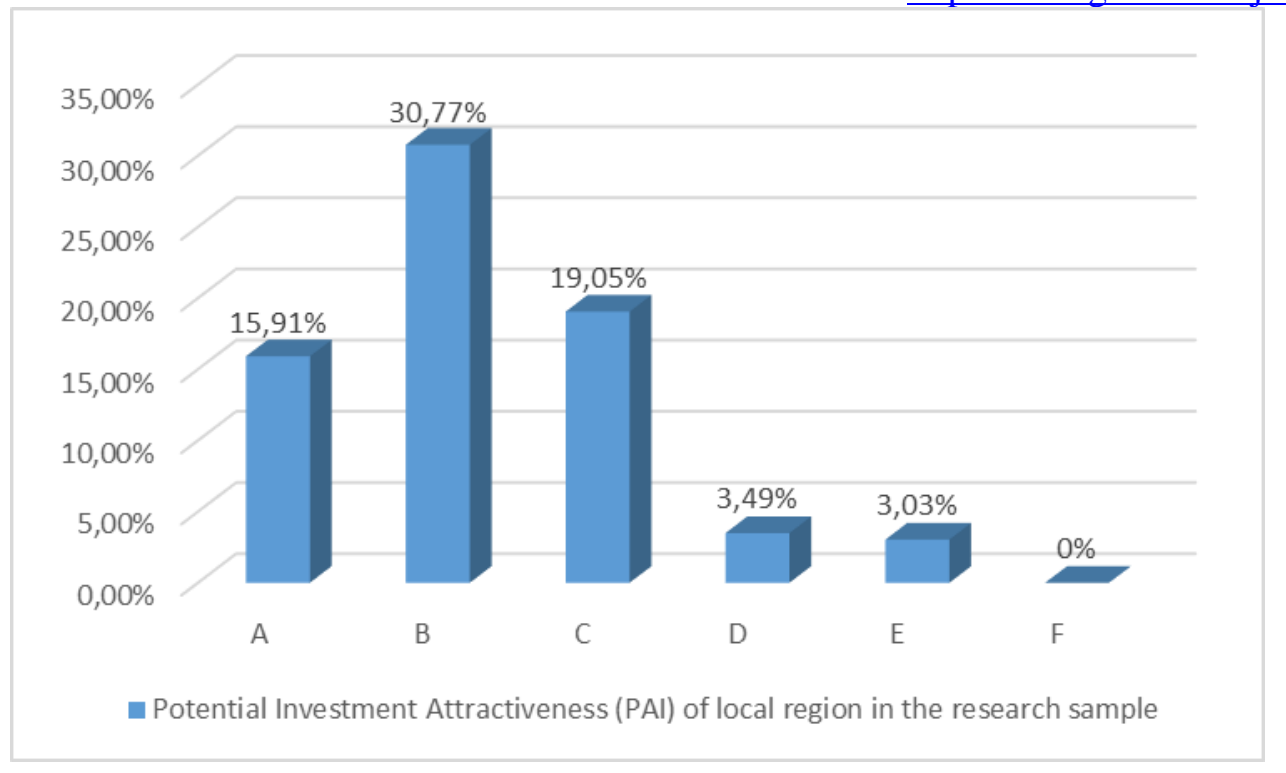

Figure 4. Percentage of local regions from the research sample with information for entrepreneurs concerning the enterprises located there and communicated through their official website and their PIA (class A-B - high, class C-D - medium, class E-F - low).

Source: Own study basing on research performed.

Among factors contributing to local region's offer for entrepreneurs, we also noticed information on labour market and fairs and exhibition organized by LG. In relation to the first one, only $7 \%$ of all investigated local regions communicated the information about labour market (in the form of local business job offer) in their official websites. The same applies to fairs, exhibitions, economic missions or economic site visits (taking into account the interests of entrepreneurs). Only $6,5 \%$ of investigated local regions communicated that information in their websites.

To verify the hypothesis, we investigated if there is correlation between potential attractiveness investment of local regions and their pro-entrepreneurial behavior. To achieve it, we used a mystery customer research method. It referred to sending communication by entrepreneur to all local regions in our sample with request to support finding a business location, finding employees, finding place to purchase or rent for conducting business activity, availability of formal investment offer and readiness for a direct meeting. These aspects relate to TC of an entrepreneur which they need to bear when selecting and deciding on locating economic activity in a defined spatial unit. Therefore, answers to this set of questions were scored by us from 0 to 5 basing on the depth of the answer given to aspects mentioned above. We analyzed local regions which earned at least 4 points out of 5 points $(80 \%)$ possible which is equivalent of a good grade in most common grading methodologies. A good grade among local regions of high PIA (class A-B), medium PIA (C-D) and low PIA (E-F) was earned by respectively on average in $14 \%, 6 \%$ and $8 \%$ of them. Relatively high demonstration thorough answers received by mystery customer from local regions of the highest PIA (class A) is less surprising that on average low PIA (class E-F) local regions achieved better results than those which PIA is of medium level (class C-D). Figure 5 presents the details. 


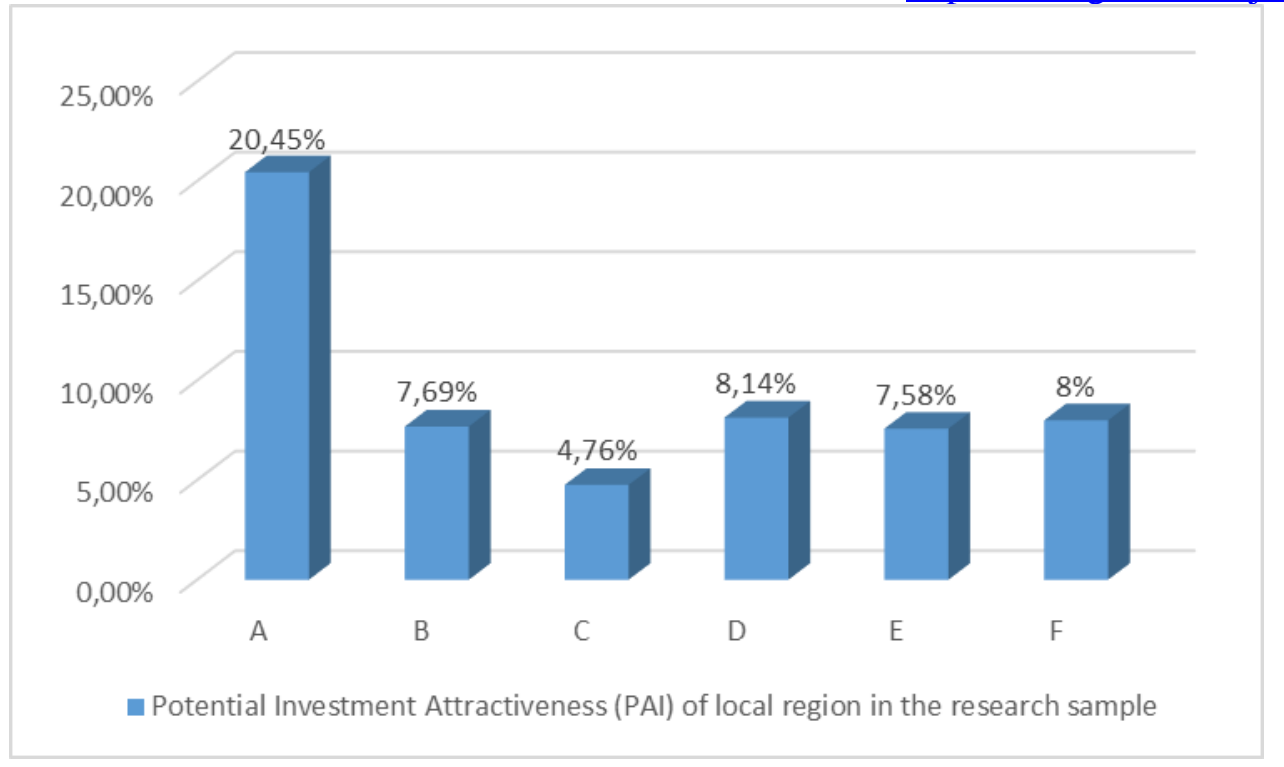

Figure 5. Percentage of local regions from the research that earned at least 4 for 5 points possible in mystery stakeholder research where interaction with LG was investigated through electronic correspondence with LG. Presented in relation to PIA of local region (class A-B high, class C-D - medium, class E-F - low).

Source: Own study basing on research performed.

We checked if local region representing particular classes from A to F (PIA) responded to the survey and to the mysterious customer more frequently as they have the higher PIA.

To achieve that we used Spearman rank test and as a result we have got a positive correlation between PIA indicator of particular local regions and their activity in responding for sent survey and for the mysterious stakeholder ( 'Spearmans $\mathrm{R}=0.157, \mathrm{p}=0.009$ ). Local regions with higher PIA answer more frequently than the rest of local regions.

Moreover, the conducted research showed that the higher PIA the local regions have, there was the higher frequency of their answer for survey. The difference in mean values between classes is significant $(p=0.02)$ in the test of variance analysis Annova rang Kruskal-Wallis, what is presented in table 2.

Table 2. Breakdown Table of Descriptive Statistics

\begin{tabular}{|c|c|c|c|}
\hline Breakdown Table of Descriptive Statistics \\
\hline Class & $\begin{array}{c}\text { Answers to the number of } \\
\text { questions (0-5) } \\
\text { Means }\end{array}$ & $\begin{array}{c}\text { Answers to the number of } \\
\text { questions (0-5) } \\
\mathrm{N}\end{array}$ & $\begin{array}{c}\text { Answers to the number of } \\
\text { questions (0-5) } \\
\text { Std.Dev. }\end{array}$ \\
\hline A-B & 1,315789 & 57 & 1,794415 \\
\hline C-D & 0,751938 & 129 & 1,436309 \\
\hline E-F & 0,648352 & 91 & 1,361157 \\
\hline All groups & 0,833935 & 277 & 1,508864 \\
\hline
\end{tabular}

Source: Own study basing on research performed. 
On the basis of the research, it can be concluded that the class A-B stands out against the rest in terms of responses to the survey. There were dependencies between the PAI indicator and the frequency of responding to the electronic survey. From pro-entrepreneurial point of view the reaction of local regions on electronic survey was not so significant as the reaction for mystery customer. In the case of a response to the electronic survey by us, the LGs express their commitment to scientific and design issues, while the answer to the mysterious customer's questions directly indicates interest in the entrepreneur.

Among all the samples of 277 local regions only $11 \%$ responded to the electronic survey, while $33.2 \%$ responded to the mysterious client question (see figure 6).

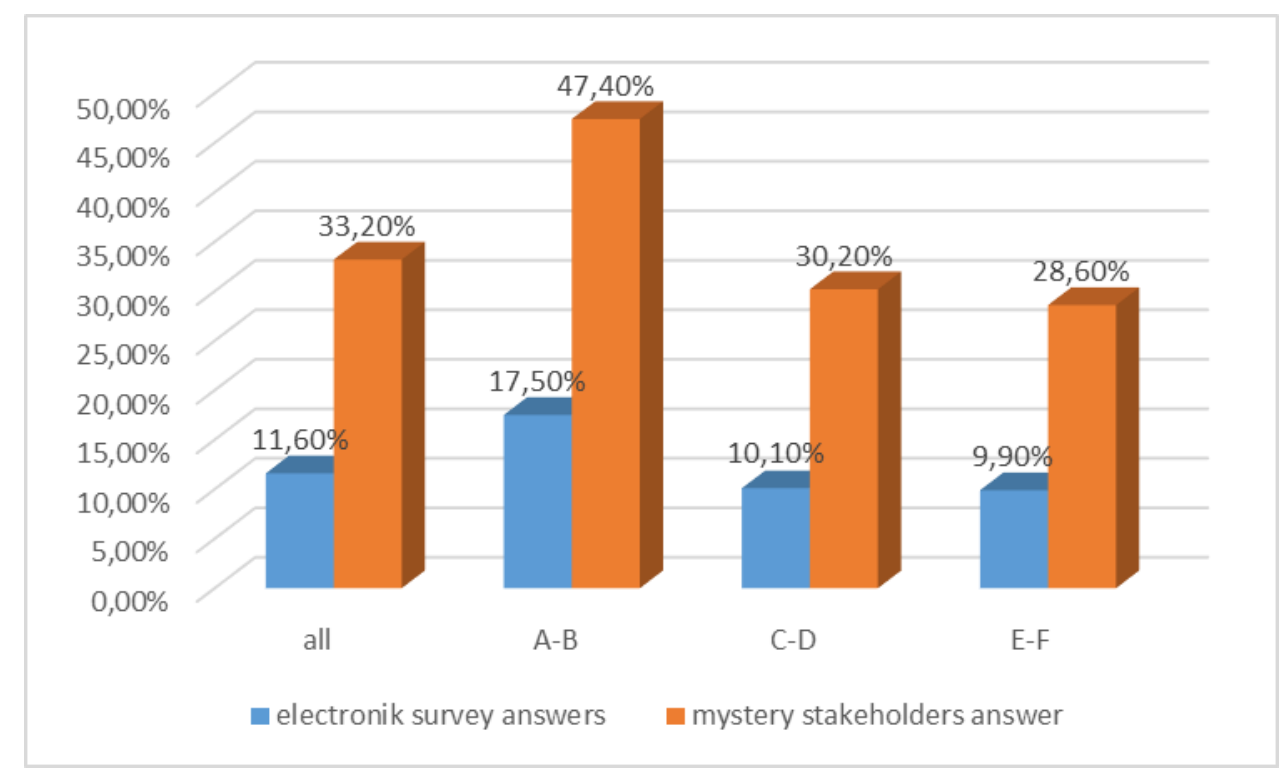

Figure 6. Percentage of local regions from the research sample which actively participated in mystery stakeholder research and in electronic survey sent to official administrative representatives of the local regions in the sample. Presented in relation to PIA (class A-B high, class C-D - medium, class E-F - low).

Source: Own study basing on research performed. 


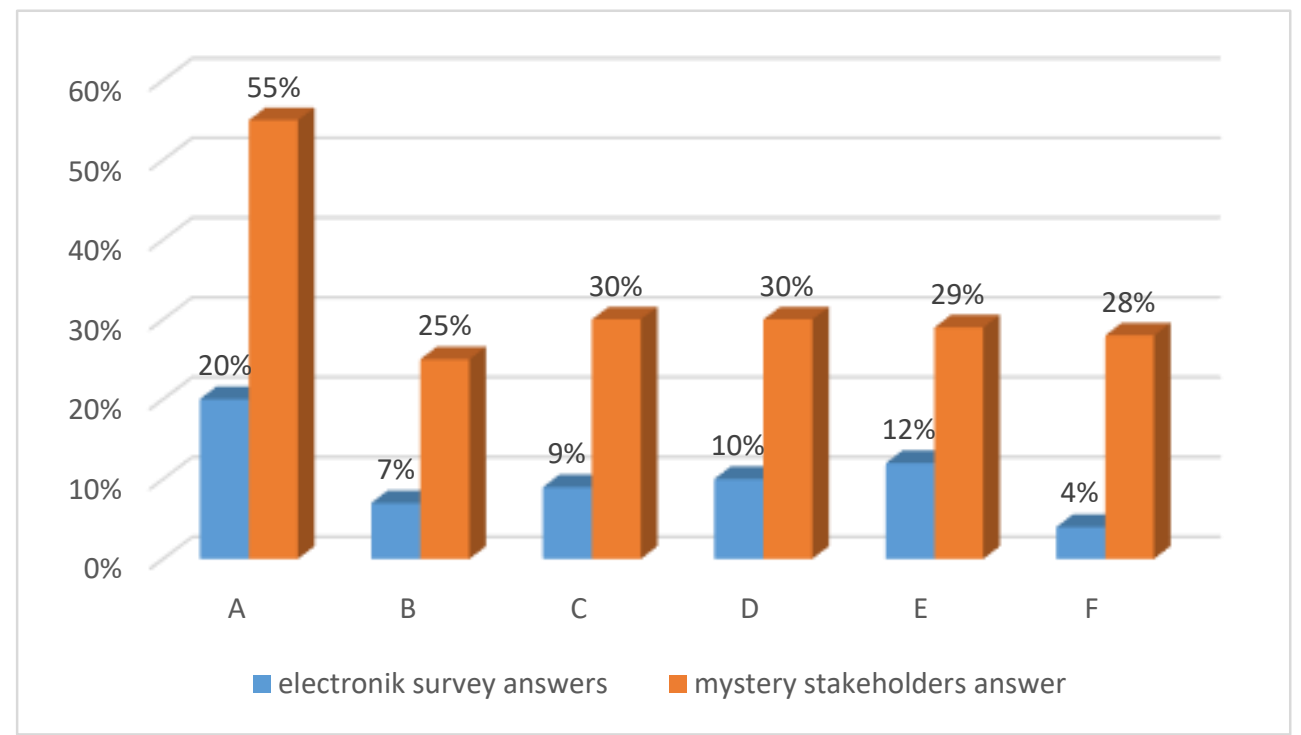

Figure 7. Percentage of local regions from the research sample which actively participated in mystery stakeholder research and in the digital survey sent to official administrative representatives of the local regions in the sample. Presented in relation to PIA and classes (class A, B, C, D, E, F).

Source: Own study basing on research performed.

We found out that the highest percentage of responses to both the electronic survey and the mystery stakeholder was noted by local regions representing class A (with the highest PIA) (see figure 7). In other groups, the relationship between the PIA class and responding survey and to mystery customer was not observed.

\section{Conclusions}

In the light of the research results, it can be stated that LGs play an important function in shaping the conditions of economic activity within the local regions. This is the way to control indirectly the activities of economic entities in compliance with the objectives of local economic development policies. As a part of the broadly understood LD, the LGs undertake many different efforts to make their local region attractive both for inhabitants and entrepreneurs (Lakshmanan and Chatterjee 2009).

Most of the LGs' activities are focused on creation and development of technical infrastructure, institutional support and use of fiscal, financial and other incentives for entrepreneurs. The fiscal, financial and other incentives, despite being elaborated in scholar literature, are relatively non-utilized in practice of LGs we have examined. In the context of decreasing TCs for economic entities, the investment incentives saving entrepreneurs time or resources might impact the investment decision and preference toward a certain location. In our research sample only $2.5 \%$ of all the local regions investigated offered on their official websites documents, instructions or content which constitute a guide for starting entrepreneurial or investment activity in the local region. Moreover, only $3.5 \%$ of all the local regions investigated offered support in setting-up an economic entity through a direct contact and individual support.

Our research shows that the most popular investment incentives offered currently by the LGs in Poland are: tax reliefs, grants and subsidies. The most interesting non-fiscal and non-financial incentives of the local regions identified in our research refer to: support in preparation of business plan, business advisory and business 


\section{ENTREPRENEURSHIP AND SUSTAINABILITY ISSUES}

ISSN 2345-0282 (online) http://jssidoi.org/jesi/

2020 Volume 7 Number 3 (June)

http://doi.org/10.9770/jesi.2020.7.3(13)

trainings, free of charge conference rooms for entrepreneurs, or free of charge accounting services for starting entrepreneurs arranged by the LGs.

As a result of statistical analysis of the collected source material, conducted with the application of Spearman's rank test, Annova rang Kruskal-Wallis variation test a weak positive correlation between PAI and mystery applicant was observed which is the starting point for further research.

In the light of these arguments and results presented above, we believe that the LGs can, with relatively nonintensive resource usage, deploy a plethora of improvements decreasing the TCs for entrepreneurs to attract them and enable them to contribute to the LD process.

As part of the implementation of the adopted research objective, the verification of the hypothesis assuming the coexistence - the higher level of PAI, the higher level of readiness and reaction of the LGs - has also been carried out. Taking into account the results of the statistical tests we stated that the hypothesis (no 1.) concerning the dependence between the level of local regions PIA and the pro-entrepreneurial behavior has not been verified positively. In the investigated phenomena, the local regions from A-B PIA class not always demonstrated the highest intensity of the studied issues.

The assumptions resulting from the research objectives have also been implemented. We presented the list of the investment incentives offered by the local regions with the highest PIA. This information can be used by other the LGs in developing strategic development plans in the context of developing local businesses.

Finally, it is necessary to underline that our research was influenced by a relatively low level of return of the survey responses that is why our conclusions are relatively general. Moreover, correlation observed in the study can become the starting point for further research. We recommend involving the LGs in an in-depth investigation of entrepreneurial behaviour of the LGs in order to check their influence on the entrepreneur's TCs as well as to improve mutual cooperation of LGs and business sector.

\section{References:}

Bagnasco, A. 1977. Tre Italie. La problematica territoriale dello sviluppo italiano. Bologna: Il Mulino.

Becattini, G. 1992. Le district marshallien: une notion socio-économique [The Marshallian district: a socio-economic concept] , in Benco, G.; Lipietz, A. (Eds.). Les regions qui gagnent. PUF, Paris, 35-55.

Bingham, R. D.; Mier, R. (Eds.) 1993. Theories of local economic development. Perspectives from across the disciplines. Newbury Park, SAGE Publication.

Birkhölzer, K. 2009. The Role of Social Enterprise in Local Economic Development. The 2nd EMES International Conference on Social Enterprise, Trento.

https://ccednetrcdec.ca/sites/ccednetrcdec.ca/files/The\%20Role\%20of\%20Social\%20Enterprise\%20in\%20Local\%20Economic\%20Develo pment.\%20EMES\%20Conference\%20papers.pdf

Bond, P. 2005. Debates in Local Economic Development Policy and Practice. in: Rogerson, C. (ed.) 2005. Local Economic Development in the Changing World. New York: Routledge, pp. 57-74. https://doi.org/10.4324/9781351322607

Capello, R. 2011. Location, Regional Growth and Local Development Theories, AESTIMUM 58, Giugno 2011: 1-25. http://dx.doi.org/10.13128/Aestimum-9559

Collinge, C. 1992. The Dynamics of Local Intervention: Economic Development and the Theory of Local Government. Urban Studies, 29(1), 57-75. https://doi.org/10.1080/00420989220080051 


\section{ENTREPRENEURSHIP AND SUSTAINABILITY ISSUES}

ISSN 2345-0282 (online) http://jssidoi.org/jesi/

2020 Volume 7 Number 3 (June)

http://doi.org/10.9770/jesi.2020.7.3(13)

Dzwigol, H. et al. 2019. An Entrepreneurship Model for Assessing the Investment Attractiveness of Regions. Journal of Entrepreneurship Education 22: 1-7. https://www.abacademies.org/articles/An-entrepreneurship-model-for-assessing-the-investment-1528-2651-22-S1339.pdf

Eddelani, O.; El Idrissi, N. E.; Monni, S. 2019. Territorialized forms of production in Morocco: provisional assessment for an own model in gestation. Insights into Regional Development 1(1): 6-18. https://doi.org/10.9770/ird.2019.1.1(1)

Godlewska-Majkowska, H. (Ed.) 2011. Atrakcyjność inwestycyjna regionów jako uwarunkowanie przedsiębiorczych przewag konkurencyjnych. Wybrane fragmenty [Investment attractiveness of regions as a condition of entrepreneurial competitive advantages. Choosen part] SGH Collegium of Business Administration. Warsaw.

Godlewska-Majkowska, H., 2018. Investment Attractiveness of Polish Municipalities in Relation to Local Entrepreneurship. Olsztyn Econimic Journal 13, 2(2018), Wydawnictwo Uniwersytetu Warmińsko-Mazurskiego w Olsztynie, Olsztyn. Retrived from http://www.uwm.edu.pl/wne/podstrony/oej1/wydania/2018/oej_13_18_2.pdf

Hwang, K. 2015. Contracting in local public organizations: the institutional economics perspective. Journal of Public Affairs 15(3): 237242. https://doi.org/10.1002/pa.1509

Ismael, M. 2017. Transaction Costs in an Overlapping Generations Model. Economic Issues, 22(2): 61-82. https://doi.org/http://www.economicissues.org.uk/

Jac, I.; Vondrackova, M. 2017. The Perception of Selected Aspects of Investment Attractiveness by Businesses Making Investments in the Czech Republic. Ekonomie a Management, 20(3): 118-132. http://www.ekonomie-management.cz/en/archiv/

Johnson, N., Cochrane, A. 1981. Economic Policy-Making by Local Authorities in Britain and Western Germany. London: Routledge. https://doi.org/10.4324/9781315225586

Kisman, Z. A..; Tasar I. 2014. The Key Elements of Local Development. Procedia Economics and Finance 15: 1689-96. http://dx.doi.org/10.1016/S2212-5671(14)00642-X

Lakshmanan, T. R.; Chatterjee, L. 2009. New Governance Institutions in the Entrepreneurial Urban Region. Innovation 22(3): 371-91. http://dx.doi.org/10.1080/13511610903367853

Lubell, M..; Mewhirter, J. M..; Berardo, R.; Scholz, J. T. 2017. Transaction Costs and the Perceived Effectiveness of Complex Institutional Systems. Public Administration $\quad$ Review, 77(5): 668-680. $\quad$ Retrieved http://search.ebscohost.com/login.aspx?direct=true \&db=eoh\&AN=1686756\&lang=pl\&site=ehost-live

Luke, B.; Verreynne, M.; Kearins, K. 2010. Innovative and entrepreneurial activity in the public sector: The changing face of public sector institutions. Innovation: Management, Policy \& Practice 12: 138-153. https://doi.org/10.5172/impp.12.2.138

Marks-Bielska, R., Serocka, I. 2018. The Impact of Warmia and Masuria Local Authorities on Entrepreneurship Development in the Business Location Factors Context, Folia Oeconomica Stetiniensa 18(1): 67-81. https://doi.org/10.2478/foli-2018-0006

Marks-Bielska, R.,; Lizińska, W.; Babuchowska, K.; Wojarska, M. 2017 Report from research project Sprawność instytucjonalna vs. lokalny rozwój gospodarczy - czynniki kształtujące i interakcje (Institutional efficiency vs. local economic development - shaping factors and interactions), Olsztyn. Retrieved from http://www.uwm.edu.pl/konferencjakpgir/pliki/raport_z_projektu.pdf

Maron, B. 2013. Review of Local Barriers to Investment in the Context of Investment Attractiveness of Polish Cities. Economic University in Katowice. Economic Studies. $\quad 155$ 241-251. $\quad$ Retrived https://www.ue.katowice.pl/fileadmin/_migrated/content_uploads/18_B.Marona_Bariery_realizacji_inwestycji....pdf

Moschidis, O.; Ismyrlis, V. 2018. Citizens' Participation in Local Economic Development and Administration: An Exploratory Statistical Analysis, South-Eastern Europe Journal of Economics 16(1): 35-54. Retrieved from http://search.ebscohost.com/login.aspx?direct=true \&db=eoh\&AN=EP129616277\&lang=pl\&site=ehost-live

Nowicki, M. (Ed.) 2012. The investment attractiveness of the regions and the sub-regions of Poland. The Gdańsk Insitute for Market Economics (GIME), Gdańsk. 


\section{ENTREPRENEURSHIP AND SUSTAINABILITY ISSUES}

ISSN 2345-0282 (online) http://jssidoi.org/jesi/

2020 Volume 7 Number 3 (June)

http://doi.org/10.9770/jesi.2020.7.3(13)

O'Gorman, C.; Kautonen M. 2004. Policies to Promote New Knowledge-Intensive Industrial Agglomerations. Entrepreneurship and Regional Development 16(6): 459-79. http://dx.doi.org/10.1080/0898562042000224369

Orynbassarova, Y., Abzalbek, E., Pritvorova, T., Petrenko, Y. 2019. Regional and product profile of post-industrial services in the economy of Kazakhstan. Insights into Regional Development 1(4): 343-355. https://doi.org/10.9770/ird.2019.1.4(5)

Petrenko, Y.; Vechkinzova, E.; Antonov, V. 2019. Transition from the industrial clusters to the smart specialization of the regions in Kazakhstan, Insights into Regional Development 1(2): 118-128. https://doi.org/10.9770/ird.2019.1.2(3)

Pike, A.; Rodriguez-Pose, A.; Tomaney, J. 2017. Local and Regional Development, London: Routledge. https://doi.org/10.4324/9781315767673

Roman, A.; Rusu, V. D.; Stoica, O. 2017. Institutional Environment And Economic Development In Eu Countries: The Impact On New Business Formation, Transformations in Business \& Economics 17 2B(44B): 579-603. http://www.transformations.knf.vu.lt/44b/article/inst

Sasongko, G., Hunga, I.A.R., Julana, A.S.N. Wahyudi, Y., Paulus Leliak, P., Huruta, A.D. 2019. Public policy for housing development: a case study on housing development in Semarang Regency - Indonesia. Insights into Regional Development 1(3): 280-300. https://doi.org/10.9770/ird.2019.1.4(1)

Šebestová, J.; Klepek, M.; Čemerková, C.; Adámek, P. 2015. Regional Entrepreneurship Culture and the Business Lifecycle: Patterns from the Moravian-Silesian Region. Acta Universitatis Agriculturae et Silviculturae Mendelianae Brunensis 63(6): 2137-44. http://dx.doi.org/10.11118/actaun201563062137

Serocka, I. 2016. The importance of business location factors vs. the activity of Warmia and Mazury voivodeship local authorities, Research Papers of Wroctaw University of Economics 450: 224-237. http://dx.doi.org/10.15611/pn.2016.450.45

Sternberg, R. 2009. Regional Dimensions of Entrepreneurship. Foundations and Trends in Entrepreneurship 5(4): 211-340. http://dx.doi.org/10.1561/0300000024

Taylor, J.S. 2006. What Makes a Region Entrepreneurial? A Review of the Literature. Center for Economic Development Maxine Goodman Levin College of Urban Affairs Cleveland State University. Retrived from https://engagedscholarship.csuohio.edu/cgi/viewcontent.cgi?article $=1242 \&$ context $=$ urban_facpub

Tohmo, T.; Littunen, H.; Storhammar, E. 2010. Entrepreneurial and Regional Growth Activity in Findland, Journal of Enterprising Culture 18(02): 205-28. http://dx.doi.org/10.1142/s0218495810000513

Williamson, O.E. 1998. De Economist 146: 23. https://doi.org/10.1023/A:1003263908567

Wojtyna, A. 2001. Nowe kierunki badań nad ekonomiczną rolą państwa, (New directions of research on economic role of state), Ekonomista, 1: 9-40.

Xiaohong, H.; Chen, X. 2016. Empirical Effects of Entrepreneurship on Regional Development: A Chinese Local Perspective. Journal of Developmental Entrepreneurship 21(01): 1650003. http://dx.doi.org/10.1142/s1084946716500035

Zerbinati, S.; Souitaris, V. 2005. Entrepreneurship in the public sector: a framework of analysis in European local governments. Entrepreneurship and Regional Development. An International Journal 17: 43-64. https://doi.org/10.1080/0898562042000310723 


\section{Aknowledgements}

The project is financed by the Ministry of Science and Higher Education in Poland under the programme "Regional Initiative of Excellence" 2019 - 2022 project number 015/RID/2018/19 total funding amount 10721 040,00 PLN

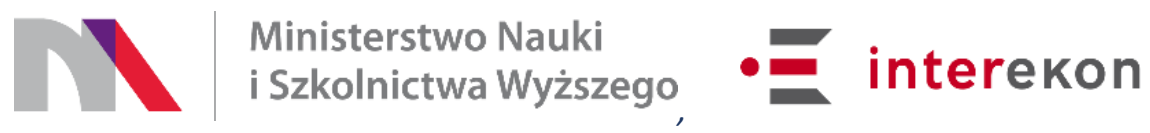

Research tools designed by us before data gathering phase have been consulted and included remarks received from representatives of Polish Investment and Trade Agency (PAIH). Authors express gratitude for time and attention given by representatives of $P A I H$ in planning phase of our research project.

Anna MEMPEL-ŚNIEŻYK (PhD) is the Assistant Professor at the Department of Spatial Economy and Local Government Administration at the Faculty of Economic Science of Wroclaw University of Economics. Her interests include: clusters, network cooperation, local and regional development.

ORCID ID: orcid.org/0000-0001-7704-4923

Niki DERLUKIEWICZ $(\mathrm{PhD})$ is the Assistant Professor at the Department of Macroeconomics at the Faculty of Economic Sciences of Wroclaw University of Economics. Her interests include: innovative economy and entrepreneurs, local and regional development, innovation strategies.

ORCID ID: orcid.org/0000-0002-3967-3048 


\section{ENTREPRENEURSHIP AND SUSTAINABILITY ISSUES}

ISSN 2345-0282 (online) http://jssidoi.org/jesi/

2020 Volume 7 Number 3 (June)

http://doi.org/10.9770/jesi.2020.7.3(13)

Tomasz PILEWICZ (Ph.D) is the Assistant Professor at the Collegium in Business Administration of Economic Science of Warsaw School of Economics. Professional MBA Entrepreneurship \& Innovation Alumnus. His research interest include: entrepreneurship, local and regional development, investment attractiveness, business location, transaction costs.

ORCID ID: orcid.org/0000-0002-3199-9959

Malgorzata ZDON-KORZENIOWSKA (Ph.D) is the Assistant Professor at the Department of Entrepreneurship and Spatial Management in the Institute of Geography of Pedagogical University of Cracow. Her research interest include: market orientation of local government, territorial marketing, management of tourism at local and regional level, regional tourism products.

ORCID ID: orcid.org/0000-0002-4970-0310

Copyright (C) 2020 by author(s) and VsI Entrepreneurship and Sustainability Center

This work is licensed under the Creative Commons Attribution International License (CC BY).

http://creativecommons.org/licenses/by/4.0/

(c) (i) Open Access 